\title{
U-Pb SHRIMP ages and tectonic setting of the Munster Suite of the Margate Terrane of the Natal Metamorphic Belt
}

\author{
P. Mendonidis ${ }^{\text {a,* }}$, R.A. Armstrong ${ }^{\text {b }}$, G.H. Grantham ${ }^{\text {c }}$ \\ a Department of Metallurgical Engineering, Vaal University of Technology, P/Bag X021, Vanderbijlpark, 1900, South Africa \\ ${ }^{\mathrm{b}}$ Research School of Earth Sciences, Australian National University, Canberra, ACT 0200, Australia \\ c Council for Geoscience, P/Bag X112, Pretoria, 0001, South Africa
}

\section{A R T I C L E I N F O}

\section{Article history:}

Received 5 March 2008

Received in revised form 26 June 2008

Accepted 26 June 2008

Available online 10 July 2008

\section{Keywords:}

Munster Suite

Natal Metamorphic Belt

Island arc

Geochronology

\begin{abstract}
A B S T R A C T
New U-Pb Zircon SHRIMP ages of 1091 \pm 7.1 Ma and 1093.1 \pm 5.8 Ma have been determined for two discrete phases of the Munster Suite. The Munster Suite is a calc-alkaline mafic to intermediate suite of intrusive igneous rocks that form part of the southern-most tectonic Terrane of the Mesoproterozoic-aged Natal Metamorphic Belt. Previously published geochemical data indicate that the discrete phases of the Suite are consanguineous and that these rocks originated within an oceanic island arc environment. The new age determinations now show that the different phases are also coeval. Moreover, the ages also indicate that the intrusions were, within statistical error, coeval with S-type granites within the Terrane. This is interpreted to indicate that magmatic underplating provided both the magma by way of a number of progressively more evolved pulses to produce the Munster Suite, as well as the heat necessary for crustal melting to produce the S-type granites within an island arc environment. Therefore, these new age determinations indicate a period of crustal growth at circa 1090 Ma. This moreover, is a maximum constraint on the age of the northwardverging structures within the Margate Terrane.
\end{abstract}

(C) 2008 International Association for Gondwana Research. Published by Elsevier B.V. All rights reserved.

\section{Introduction}

$\mathrm{U}-\mathrm{Pb}$ zircon ages have proven to be invaluable in elucidating the timing and sequence of tectonic events in many metamorphic belts (Skridlaite et al., in press; Mallmann et al., 2007; D'el-Rey Silva et al., 2007; Wang et al., 2007; Santosh et al., 2006a,b). This type of information permits the interpretation of tectonic histories of individual belts, as well as the interpretation of their tectonic setting and an understanding of crustal processes that formed and deformed them (Mallmann et al., 2007; Paulsen et al., 2007; Santosh et al., 2006a,b). Moreover, this information constitutes important evidence on which global correlations are based, which in turn, are used for reconstruction of continental evolution (Paulsen et al., 2007; D'el-Rey Silva et al., 2007; Wang et al., 2007; Casquet et al., 2006). An example of this is the need for information on the tectonic evolution of the Natal Metamorphic Belt to resolve the, currently equivocal, Neoproterozoic position of the Khalahari craton in relation to Rodinia (Jacobs et al., 2003; Dalziel et al., 2000; Jacobs et al., 1999).

The Natal Metamorphic Belt (NMB) comprises remnants of island arcs that accreted onto the southern margin of the Kaapvaal Craton (Jacobs et al., 1993), and is considered to be an extension of the Namaqualand Metamorphic Province in Southwestern Africa and the gneiss terranes of

\footnotetext{
* Corresponding author.

E-mail address: peter@vut.ac.za (P. Mendonidis).
}

Western Dronning Maud Land of East Antarctica (Nicholaysen and Burger, 1965; De Beer and Meyer, 1984; Jacobs et al., 1993).

There is a significant amount of literature on the intrusive and tectonic history of the Margate Terrane of the Natal Metamorphic Belt (NMB) (Gevers and Dunne, 1942; Du Toit, 1946; Mclver, 1963, 1966; Grantham, 1983; Talbot and Grantham, 1987; Thomas, 1988a, 1989; Jacobs et al., 1993; Mendonidis et al., 2002; McCourt et al., 2006). In particular, the intrusive history of the southern part of the Margate Terrane has been documented in detail by Grantham (1983) and Mendonidis (1989) and an excellent summary of the salient events is provided by McCourt et al. (2006).

Previously published geochronological data has indicated that the maximum age of $1091 \pm 9$ Ma for the tectonism in the Margate Terrane (Mendonidis et al., 2002) is far younger than the ages that constrain the timing of the tectonism in the Tugela Terrane where the Syn-D3 (obduction event), post-D2 Wosi granitoid Suite (now called the Mtungweni granitoids) yielded an intrusive age of $1155 \pm$ $1 \mathrm{Ma}$ (Johnston et al., 2001), confirming the suggestion that the Margate Terrane was a younger accretion to the Natal Belt (McCourt et al., 2006).

Field-based studies (Grantham, 1983; Mendonidis, 1989) have provided a relative intrusive history for the southern part of the Terrane. However, poor preservation of early (S1) fabrics in the intrusive rocks that otherwise display only a very well defined S2 foliation has necessitated further geochronological data in order to further understand the tectono-magmatic history of this Terrane. To 
this end, U-Pb SHRIMP ages for two samples from the Munster Suite were acquired in this study.

\section{Geological setting}

The Natal Metamorphic Belt (NMB) consists of three tectonic terranes (Thomas, 1989) (Fig. 1) that are interpreted as the remnants of island arcs that accreted onto the southern margin of the Kaapvaal Craton (Jacobs et al., 1993).

The Tugela Terrane comprises supracrustals of igneous and sedimentary origin that have island arc geochemical signatures (Arima et al., 2001), and that were obducted onto the southern margin of the Kaapvaal Craton (Matthews, 1972). The oldest rocks in the Tugela Terrane are the Kotangweni Tonalitic Gneisses, which pre-dated the D1-event and have an age of $1209 \pm 5 \mathrm{Ma}$ (Johnston et al., 2001). The
syn-D2 Mkondeni Diorite provided an age of $1161 \pm 9$ Ma (Johnston et al., 2001), and the post-D2 Wosi Granitoid Suite (now called the Mtungweni granitoids), which is considered to have intruded during the D3 obduction event, has an age of $1155 \pm 1$ Ma (Johnston et al., 2001). The Dulumbe paragneisses, which form the structurally highest tectonic unit, yielded a detrital zircon age of $1276 \pm 10 \mathrm{Ma}$ (Johnston et al., 2001). The southern margin of the Tugela Terrane is delineated by the Lilani-Matigulu shear zone. This shear zone also marks the southern extent of the underlying Kaapvaal Craton (Barkhuizen and Matthews, 1990), indicating that the entire Tugela Terrane overlies Archaean crust of the Kaapvaal Craton.

The Mzumbe Terrane covers a large area south of the LilaniMatigulu shear zone. The oldest rocks of this terrane are supracrustals of the Mapumulo Group, of which the meta-andesites of the Quha Formation provided an eruption age of $1235 \pm 9 \mathrm{Ma}$ (Thomas et al.,

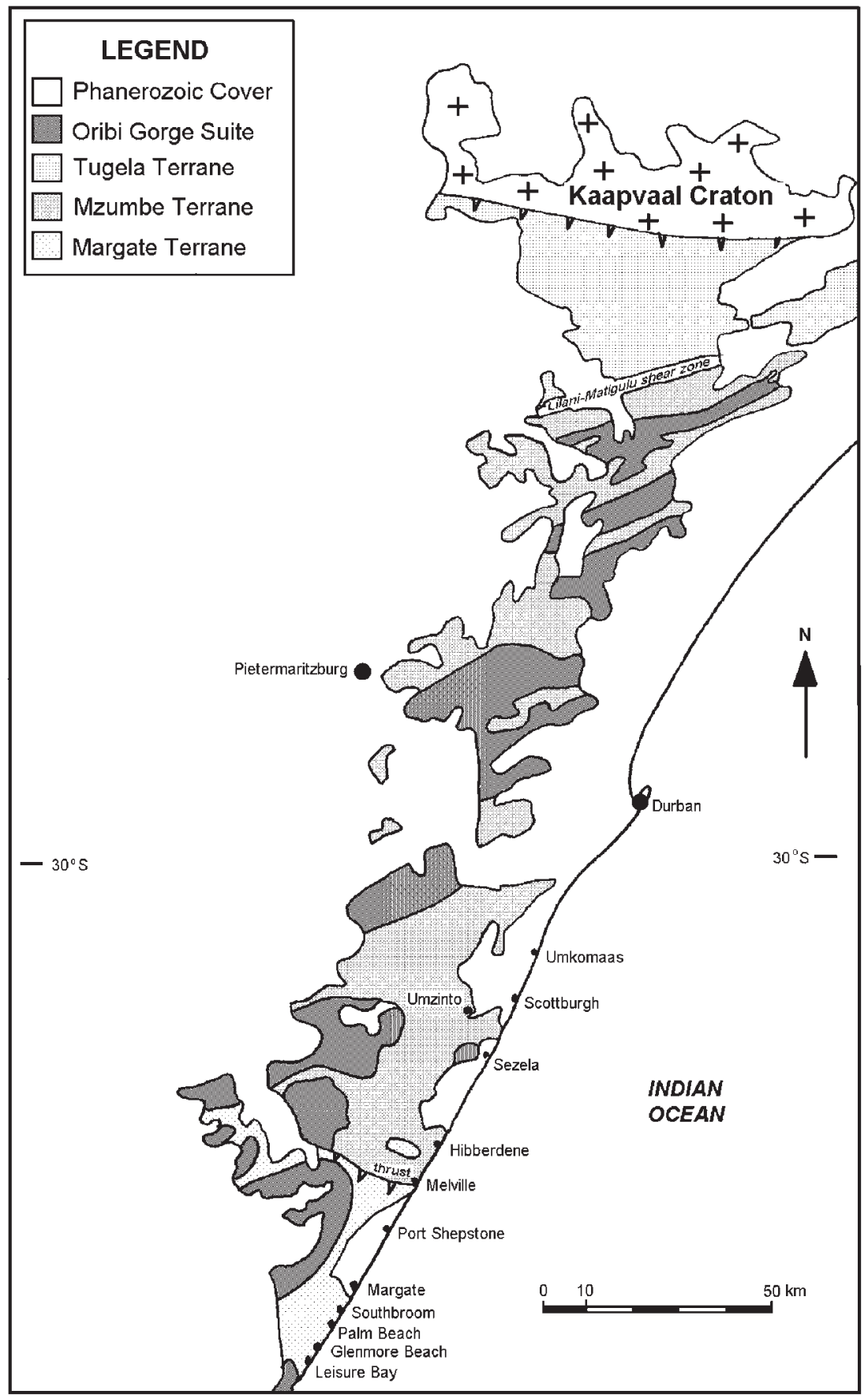

Fig. 1. Locality map showing the three terranes of the Natal Metamorphic Belt that accreted onto the southern Margin of the Kaapvaal Craton (McCourt et al., 2006). 
1999). The tonalitic orthogneisses of the Mzumbe TTG suite, which intruded the Mapumulo Group rocks, gave an age of $1207 \pm 10 \mathrm{Ma}$ (Thomas and Eglington, 1990), which provides a maximum age for the D1/M1 event in this Terrane. The gabbroic component of the Equeefa Suite gave a U-Pb SHRIMP age of $1082 \pm 2 \mathrm{Ma}$, which is also a direct age of the D2 event since this was a syn-kinematic intrusion (Data of B.M. Eglington reported in McCourt et al., 2006). A heating event at 1065 \pm $15 \mathrm{Ma}$ is indicated by U-Pb SHRIMP ages of metamorphic overgrowths on zircon grains from the Quha Formation.

A number of large charnockitic A-type plutons intruded both the Mzumbe and Margate terranes. These plutons collectively form a rapakivi granite-charnockite association with A-type geochemical characteristics (Grantham et al., 2001). Some of these plutons contain a penetrative $S_{2}$ foliation (e.g. Port Edward pluton-Grantham, 1983), whereas others have undeformed cores (Thomas, 1988b), and they have been considered to be late- to post-tectonic relative to $D_{2}$ (Thomas et al., 1993a,b). U-Pb SHRIMP ages of these plutons, reported by Thomas et al. (1993a,b) and Eglington et al. (2000), range from $\sim 1025$ to $1100 \mathrm{Ma}$, and Eglington et al. (2003) have identified two distinct pulses of magmatism at $\sim 1070 \mathrm{Ma}$ and $\sim 1030 \mathrm{Ma}$.

The Margate Terrane lies south of the Melville Thrust (Fig. 1) and can be visualized in terms of sheets of mafic and granitic rocks that intruded layers of metasedimentary rocks all of which define northward-verging F2 folds (e.g. Talbot and Grantham, 1987). The lithostratigraphy of the Terrane, based on field relationships, places the Leisure Bay metasedimentary rocks as the oldest lithology that was intruded by the Glenmore Granite, which was, in turn intruded by the Munster Suite metabasites, and subsequently by the Margate Suite granites and then the Oribi Gorge Suite granitoids (Grantham, 1983; Mendonidis, 1989; McCourt et al., 2006). The tectonic history of the Margate Terrane has been outlined by Talbot and Grantham (1987), Mendonidis and Strydom (1989) and Mendonidis and Grantham (2003). Essentially, the Terrane has undergone two tectonic events, D1/M1 and D2/M2. D1 is characterized by a S1 fabric and rootless isoclinal F1 folds in the Leisure Bay metasedimentary rocks and locally preserved S1 fabrics in some granites. M1 is characterized by lowpressure granulite facies metamorphism and anticlockwise cooling paths. D2 involved northward-verging folding of all the lithologies and the development of a pervasive southward-dipping S2 foliation. The M2 metamorphism caused a second period of anatexis at higher pressures than those of M1.

Radiometric ages for a number of lithologies from the Margate Terrane have been determined (Table 1). In addition to these, detrital zircon grains from the Leisure Bay Formation, which is considered to be the oldest lithological unit in the Margate Terrane (Grantham, 1983; Mendonidis, 1989; Thomas, 1989), have yielded U-Pb SHRIMP ages ranging between $\sim 1730$ and $\sim 1196 \mathrm{Ma}$ (R.A. Armstrong, unpublished data).

Mendonidis et al. (2002) concluded that the $1091 \pm 9$ Ma age for the Glenmore Granite provides a maximum age for the D1/M1 event that affected the rocks of the Margate Terrane, since the Glenmore Granite preserves evidence of S1 and S2 fabrics (Talbot and Grantham,1987). The younger intrusive lithologies were considered to have post-dated D1 because they do not preserve a S1 fabric. However, Mendonidis and Strydom (1989) reported the presence of preserved S1 fabrics in granites of the Margate Suite, suggesting that although the Munster does not

Table 1

Published radiometric ages of lithologies of the Margate Terrane of the Natal Metamorphic Belt

\begin{tabular}{|c|c|c|}
\hline Lithology & Age & Authors \\
\hline Sikombe granite & $1181 \pm 15 \mathrm{Ma}$ [U-Pb SHRIMP] & Thomas et al. (2003) \\
\hline Glenmore granite & $1091 \pm 9 \mathrm{Ma}$ [U-Pb SHRIMP] & Mendonidis et al. (2002) \\
\hline $\begin{array}{l}\text { Port Edward pluton } \\
\text { (Oribi Gorge Suite) }\end{array}$ & $1025 \pm 8 \mathrm{Ma}[\mathrm{U}-\mathrm{Pb}$ SHRIMP] & Eglington et al. (2003) \\
\hline $\begin{array}{l}\text { Mbizana microgranite } \\
\text { dykes }\end{array}$ & $1026 \pm 3$ Ma [U-Pb SHRIMP] & Thomas et al. (1993a, b) \\
\hline
\end{tabular}

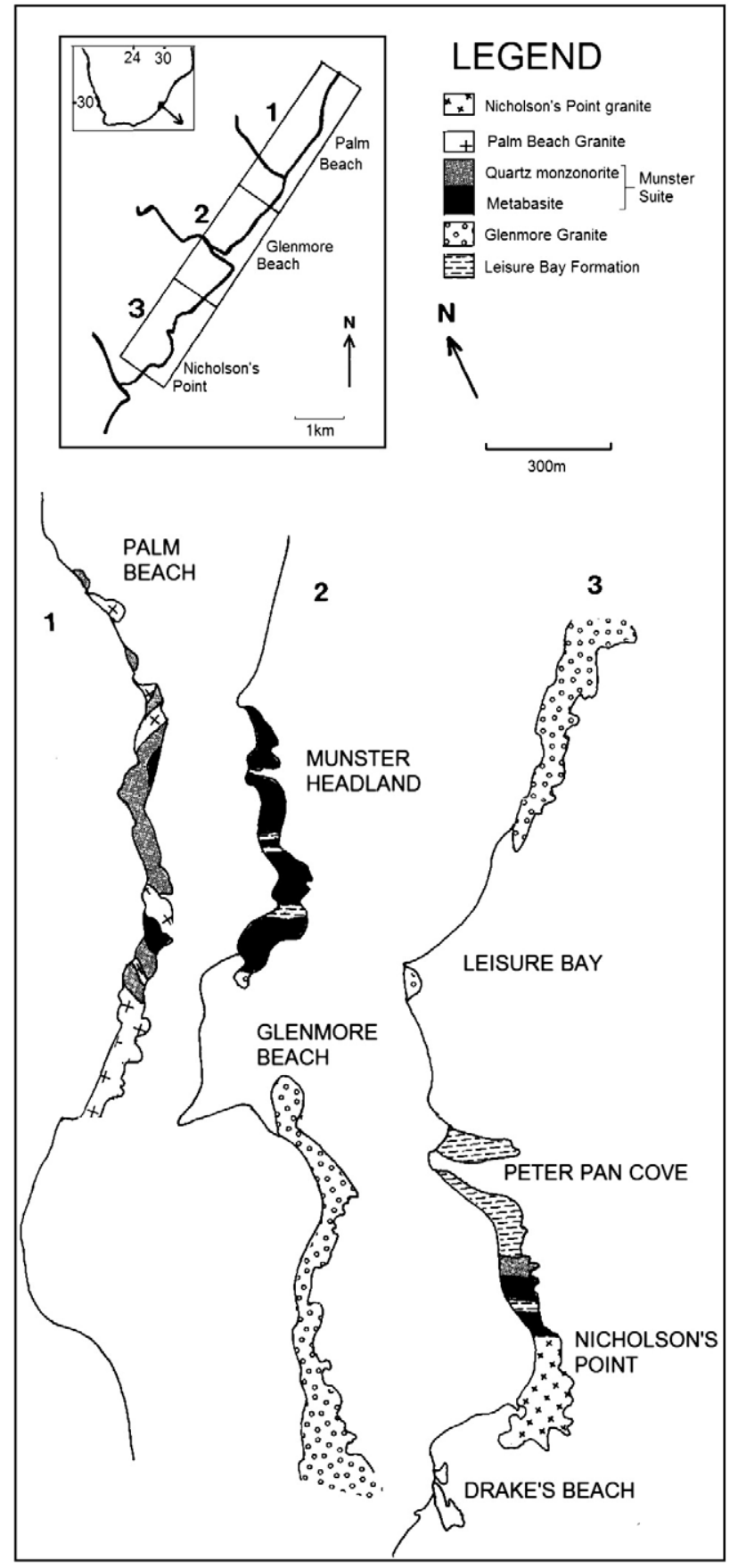

Fig. 2. Map showing the littoral distribution of the different phases of the Munster Suite.

preserve a S1 fabric it did predate D1. It may be pertinent to note that the preserved S1 foliations in both the Margate and Glenmore granites are restricted to localities adjacent to folded contacts against the Leisure Bay metasedimentary rocks. The ages of the S1 and S2 fabric in the Margate Terrane are constrained between a minimum of $1026 \mathrm{Ma}$, which is the age determined on the undeformed Mbizana microgranite dykes (Thomas et al., 1993a,b), and a maximum of $1091 \pm 9$ Ma, which is the age of the Glenmore Granite (Mendonidis et al., 2002).

\section{The Munster Suite}

The Munster Suite comprises folded sheet-like bodies of mafic to intermediate orthogneisses that have a very strongly developed southward-dipping S2 foliation. These rocks are intrusive into the 

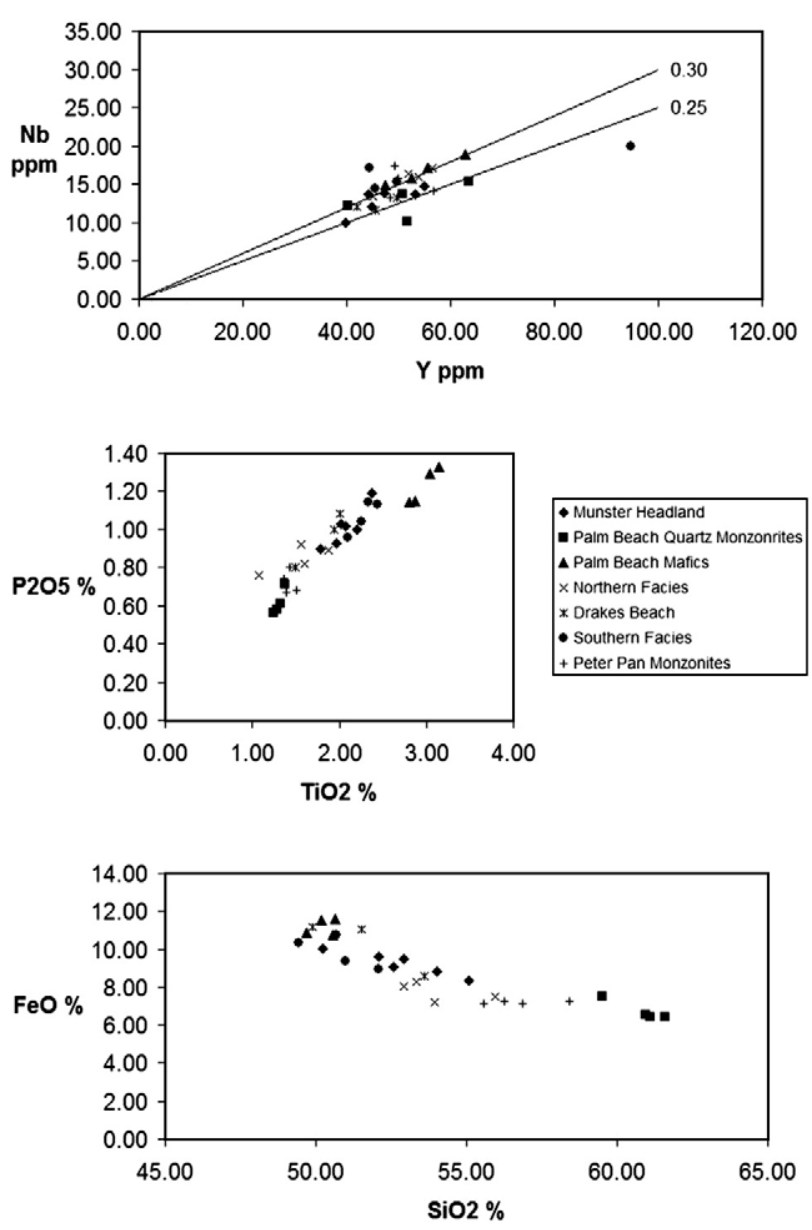

Fig. 3. Bivariate plots of the whole-rock geochemical data of the Munster Suite showing the constant $\mathrm{Nb} / \mathrm{Y}$ ratio and smooth trends that suggest consanguinity between the various intrusive phases.

metasedimentary Leisure Bay granulites and the Glenmore Granite (Mendonidis and Strydom, 1989). Rocks of this suite vary compositionally from medium-grained, quartz-free, two-pyroxene mafic granulite (metabasites) to coarse-grained, porphyritic, two-pyroxene quartz-monzonorite (mangerite) (Mendonidis and Grantham, 1989). The distribution of these rocks is presented in Fig. 2. Detailed petrographic and geochemical descriptions are given by Mendonidis and Grantham (1989).

The different phases, namely the medium-grained metabasites, porphyritic monzonites and quartz-monzonites, crop out at different localities along the southern Natal littoral (Fig. 2). Consanguinity was demonstrated geochemically by Mendonidis and Grantham (1989) in terms of smooth trends on Harker diagrams and consistent $\mathrm{Nb} / \mathrm{Y}$ ratios (Fig. 3). Grantham (1983) found field evidence that the monzonorites post-dated the metabasites. This led him to conclude that the magma was tapped progressively from a deep-seated evolving magma chamber.

Whole-rock geochemical data published in Mendonidis and Grantham (1989) show that the Munster Suite is calc-alkaline in nature (Fig. 4). On a Pearson-type spidergam, the incompatible element pattern of the Munster Suite data is very similar to that of modern-day island arcs, but enriched for each element (Fig. 5). On the Na-Nb-Sr discrimination diagram (Vermeesch, 2006) the data plot in the island arc basalt field, whereas on the Ti-Si-Sr diagram (Vermeesch, 2006) the data straddle the island arc and the oceanic island basalt fields (Fig. 6). The data fall well within the oceanic island arc region on the TiO2P2O5-MnO diagram of Mullen (1983) (Fig. 6). On the Ti-Zr-Y of
Meschede (1986) and the Nb-Zr-Y diagram of Pearce and Cann (1973), many of the data points fall outside the indicated regions, suggesting a $\mathrm{Zr}$ enrichment in the samples (Fig. 7). Similarly, on the $\mathrm{Zr} / \mathrm{Y}$ versus $\mathrm{Zr}$ discrimination diagram (Pearce and Norry, 1979) the data fall in the "within plate basalt" region characterized by high Zr contents (Fig. 7).

\section{Geochronology}

\subsection{Sampling}

Two samples were collected, one of the quartz-monzonorites from the Palm Beach exposures (sample PM07/1), and one of the medium-grained mafic granulites from the Munster Headland (sample PM07/4).

Both samples were submitted to the Council for Geoscience at Pretoria for zircon extraction. At the Research School of Earth Science (Australian National University) zircon grains were handpicked and mounted in epoxy and polished.

\subsection{Analytical procedure}

Standards used for SHRIMP analyses were the zircon standard AS3 (Duluth Complex gabbroic anorthosite; Paces and Miller, 1989) and the RSES standard SL13. The SHRIMP data were reduced in a manner similar to that described by Compston et. al. (1992) and Williams and Claesson (1987). U/Pb ratios in the unknowns were normalised to a ${ }^{206 *} \mathrm{~Pb} /{ }^{238} \mathrm{U}$ value of 0.1859 (equivalent to an age of $1099.1 \mathrm{Ma}$ ) for AS3. The $U$ and Th concentrations were determined relative to those measured in the SL13 standard. Correction for common Pb was made from the measured ${ }^{204} \mathrm{~Pb}$ and the appropriate common $\mathrm{Pb}$ isotopic compositions assuming the Cumming and Richards (1975) model.

\subsection{Quartz-monzonorites from the Palm Beach exposures (sample PM07/1)}

Zircon grain morphology was studied under cathodoluminescence. The zircons were mostly anhedral and fractured with only occasional subhedral grains preserving prism faces (Fig. 8). Most zircons showed metamorphic rounding and resorption features. Most grains appeared to be magmatic, but many of the grains were zoned and some structurally complex with zones of high $U$ and Th contents and metamictisation contrasting with less structured areas. Some of these zones possibly represent inherited cores. Metamorphic rims are commonly present, characterized by high $\mathrm{U}$ and Th contents.

The data from the quartz-monzonoritic sample (PM07/1) are presented in Table 2. A total of 19 spots on 16 grains were analysed, of

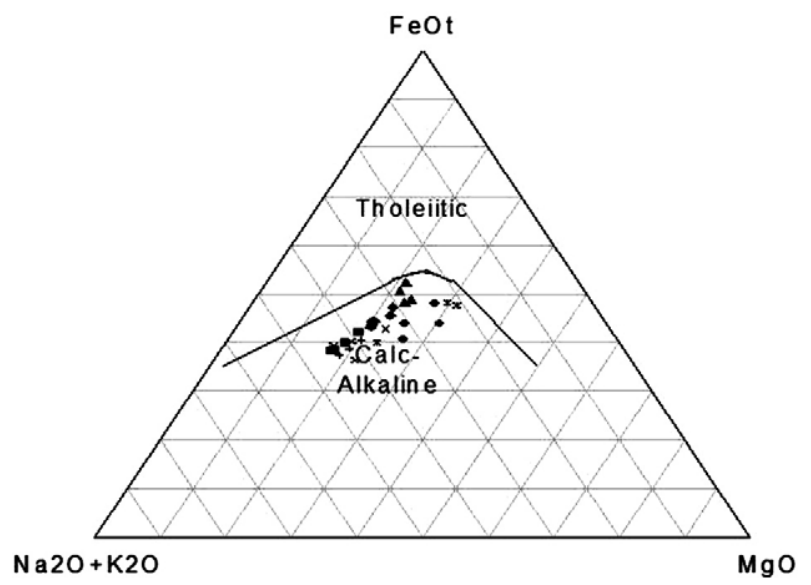

Fig. 4. AFM plot of Irvine and Baragar (1971) showing the calc-alkaline nature of the Munster Suite rocks. 

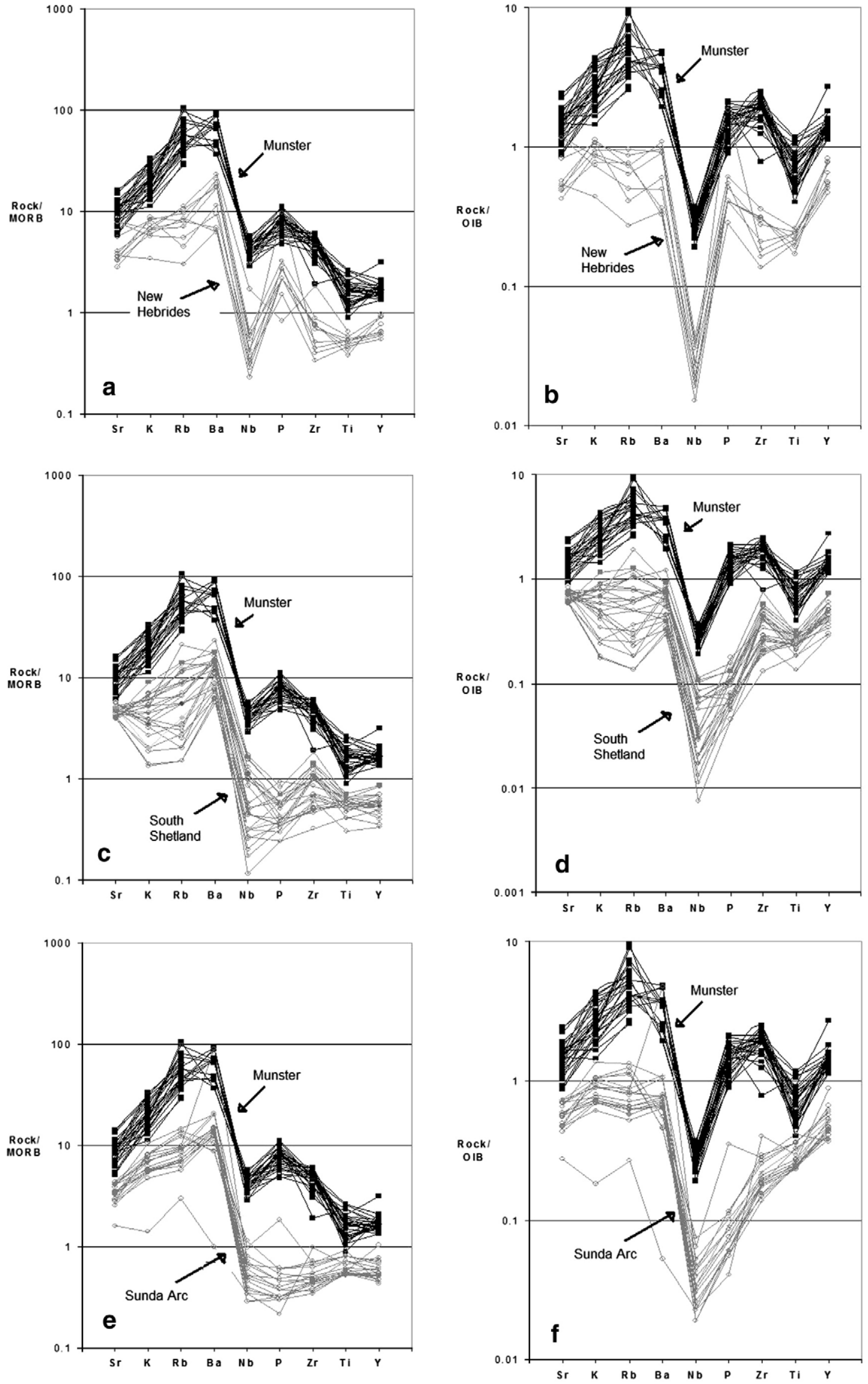

Fig. 5. Pearson-type spider diagrams comparing the incompatible element concentrations to those of some modern-day island arcs. The number of elements used in the diagrams was constrained by the data available in Mendonidis and Grantham (1989). The diagrams on the left are MORB-normalised (Pearce, 1983) and those on the right normalized to the average oceanic island arc (Sun, 1980). Data for the modern-day island arcs are from Mozier et al. (1997) (New Hebrides), Machado et al. (2005) (South Shetland Arc) and Elburg et al. (2007) (Sunda Arc). 

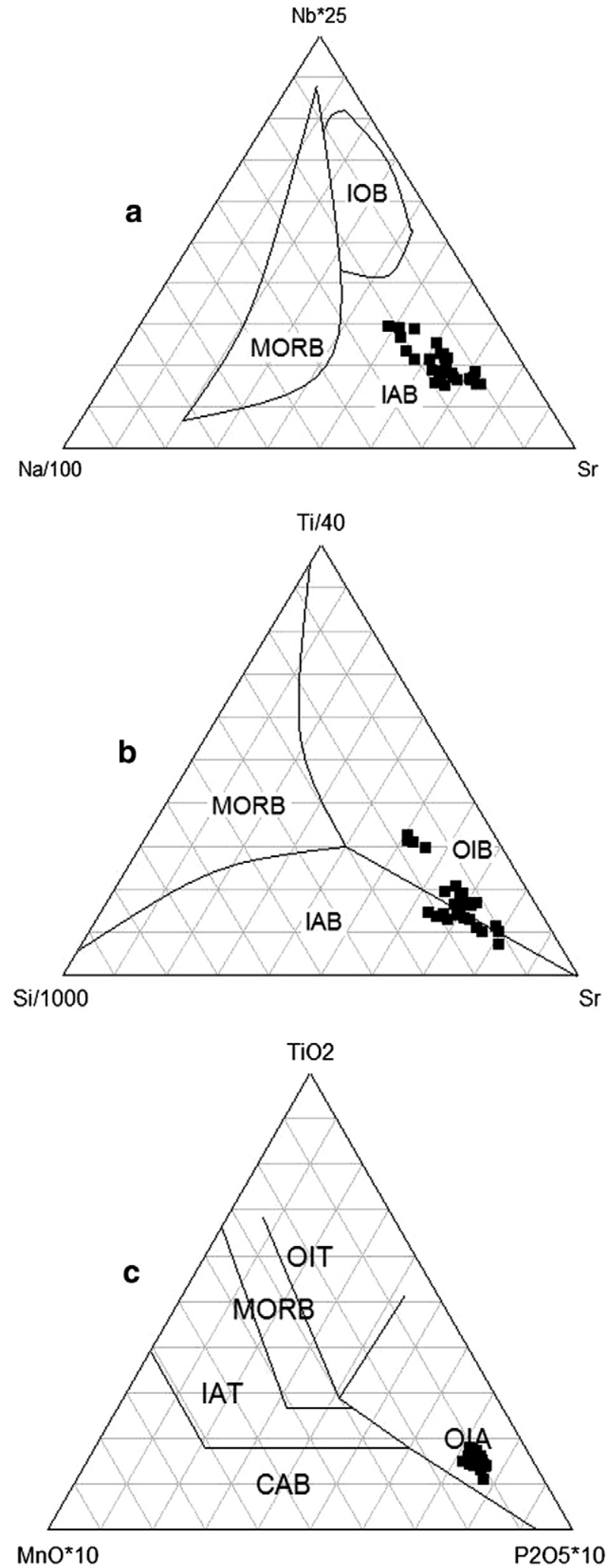

Fig. 6. Geochemical tectonic discrimination ternary diagrams: a. Nb-Na-Sr (Vermeesch, 2006) b. Ti-Si-Sr (Vermeesch, 2006) c. TiO2-MnO-P2O5 (Mullen, 1983). MORB =mid ocean ridge basalt; $\mathrm{OIB}=$ oceanic island basalt; $\mathrm{IAB}=$ island $\operatorname{arc}$ basalt; $\mathrm{OIA}=$ oceanic island alkali basalt, $\mathrm{OIT}=$ oceanic island tholeiite; $\mathrm{CAB}=$ island arc calc-alkaline basalt; IAT = island arc tholeiite.

which 12 were considered to be on magmatic grains/zones. These generated an age of $1091 \pm 7.1 \mathrm{Ma}$ (Fig. 9), which probably represents the age of magmatic crystallization of the quartz-monzonorite.
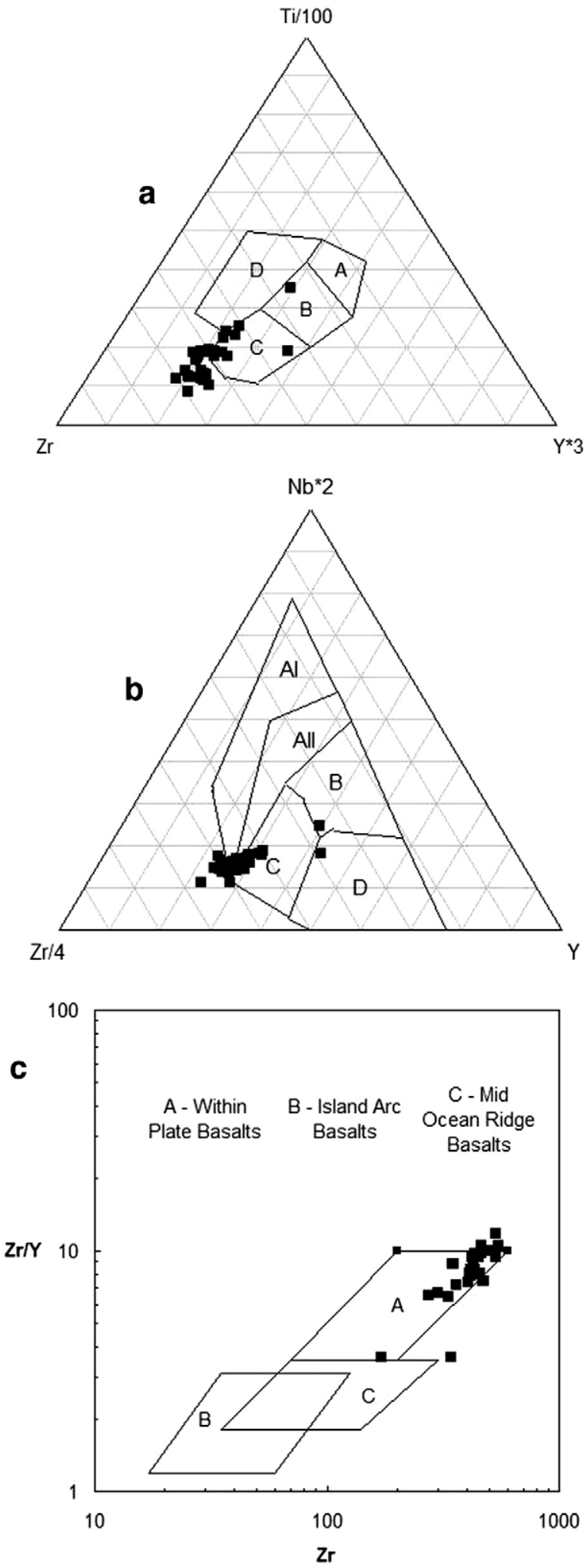

Fig. 7. Geochemical tectonic discrimination diagrams: a. Ti-Zr-Y ternary diagram after Pearce and Cann (1973); $A=$ island arc tholeiites, $B=$ mid ocean ridge basalts, $C=$ calc-alkali basalts, $\mathrm{D}=$ within plate basalts. b. $\mathrm{Zr}-\mathrm{Nb}-\mathrm{Y}$ ternary diagram after Meschede (1986); $\mathrm{AI}=$ within plate alkali basalts, $\mathrm{AII}=$ within plate alkali basalts and tholeiites, $\mathrm{B}=\mathrm{E}$-type MORB, $C=$ within plate tholeiites and volcanic arc basalts, $D=N$-type MORB and volcanic arc basalts. c. Zr/Y versus Zr plot of Pearce and Norry (1979); $A=$ volcanic arc basalts, B= MORB, $\mathrm{C}=$ within plate basalts, $\mathrm{D}=\mathrm{MORB}$ and volcanic arc basalts, E-type MORB and with plate basalts. 
Table 2

Summary of SHRIMP U-Pb zircon data for sample PM07/1

\begin{tabular}{|c|c|c|c|c|c|c|c|c|c|c|c|c|c|c|c|c|c|}
\hline $\begin{array}{l}\text { Grain } \\
\text { spot }^{a}\end{array}$ & $\begin{array}{l}\% \\
{ }^{206} \mathrm{~Pb}_{\mathrm{c}}\end{array}$ & $\begin{array}{l}\mathrm{ppm} \\
\mathrm{U}\end{array}$ & $\begin{array}{l}\mathrm{ppm} \\
\text { Th }\end{array}$ & $\begin{array}{l}{ }^{232} \mathrm{Th} / \\
{ }^{238} \mathrm{U}\end{array}$ & $\begin{array}{l}\mathrm{ppm} \\
{ }^{206} \mathrm{~Pb}^{*}\end{array}$ & $\begin{array}{l}\text { (1) }{ }^{206} \mathrm{~Pb} \\
{ }^{238} \mathrm{U} \text { age }\end{array}$ & & $\begin{array}{l}(1)^{207} \mathrm{Pl} \\
{ }^{206} \mathrm{~Pb} \text { ag }\end{array}$ & & $\begin{array}{l}\% \\
\text { discordant }\end{array}$ & $\begin{array}{l}(1)^{207} \mathrm{~Pb}^{*} / \\
{ }^{206} \mathrm{~Pb}^{*}\end{array}$ & $\pm \%$ & $\begin{array}{l}(1)^{207} \mathrm{~Pb}^{*} / \\
{ }^{235} \mathrm{U}\end{array}$ & $\pm \%$ & $\begin{array}{l}(1)^{206} \mathrm{~Pb}^{*} / \\
{ }^{238} \mathrm{U}\end{array}$ & $\pm \%$ & $\begin{array}{l}\text { Err } \\
\text { corr }\end{array}$ \\
\hline $1.1 \mathrm{r}$ & 0.20 & 111 & 57 & 0.53 & 16.8 & 1044 & \pm 12 & 1057 & \pm 24 & 1 & 0.07457 & 1.2 & 1.807 & 1.7 & 0.1757 & 1.2 & 0.710 \\
\hline $1.2 \mathrm{~m}$ & 0.00 & 829 & 181 & 0.23 & 133 & 1101 & \pm 10 & 1096.5 & \pm 6.4 & 0 & 0.07606 & 0.32 & 1.954 & 1.1 & 0.1863 & 1 & 0.955 \\
\hline $1.3 \mathrm{c}$ & 0.00 & 232 & 99 & 0.44 & 36.8 & 1092 & \pm 13 & 1119 & \pm 12 & 2 & 0.07693 & 0.6 & 1.957 & 1.4 & 0.1845 & 1.3 & 0.903 \\
\hline $2.1 \mathrm{~m}$ & 0.07 & 64 & 38 & 0.61 & 10.4 & 1120 & \pm 14 & 1099 & \pm 41 & -2 & 0.0762 & 2.1 & 1.992 & 2.5 & 0.1897 & 1.4 & 0.558 \\
\hline $3.1 \mathrm{~m}$ & 0.00 & 516 & 188 & 0.38 & 81.9 & 1094 & \pm 11 & 1077.7 & \pm 8.5 & -2 & 0.07534 & 0.42 & 1.92 & 1.1 & 0.1849 & 1.1 & 0.928 \\
\hline $4.1 \mathrm{~m}$ & 0.00 & 358 & 110 & 0.32 & 56.7 & 1092 & \pm 11 & 1088 & \pm 10 & 0 & 0.07574 & 0.51 & 1.927 & 1.2 & 0.1846 & 1.1 & 0.903 \\
\hline $5.1 \mathrm{c}$ & 0.08 & 106 & 78 & 0.76 & 16.8 & 1092 & \pm 13 & 1109 & \pm 21 & 2 & 0.07653 & 1.1 & 1.948 & 1.7 & 0.1847 & 1.3 & 0.767 \\
\hline $5.2 \mathrm{r}$ & - & 1259 & 42 & 0.03 & 140 & 786.2 & \pm 7.6 & 1015.5 & \pm 6.4 & 23 & 0.07305 & 0.32 & 1.307 & 1.1 & 0.1297 & 1 & 0.956 \\
\hline $6.1 \mathrm{~m}$ & 0.00 & 508 & 213 & 0.43 & 80.6 & 1092 & \pm 11 & 1087.1 & \pm 8.7 & 0 & 0.0757 & 0.43 & 1.927 & 1.1 & 0.1846 & 1.1 & 0.926 \\
\hline $7.1 \mathrm{~m}$ & 0.00 & 578 & 121 & 0.22 & 91 & 1085 & \pm 11 & 1065.1 & \pm 8.5 & -2 & 0.07487 & 0.42 & 1.893 & 1.1 & 0.1833 & 1.1 & 0.929 \\
\hline $8.1 \mathrm{~m}$ & 0.00 & 622 & 234 & 0.39 & 100 & 1106 & \pm 11 & 1095.9 & \pm 9.4 & -1 & 0.07603 & 0.47 & 1.962 & 1.2 & 0.1872 & 1.1 & 0.913 \\
\hline $9.1 \mathrm{~m}$ & 0.00 & 516 & 217 & 0.43 & 80.9 & 1080 & \pm 11 & 1096 & \pm 8.8 & 1 & 0.07603 & 0.44 & 1.912 & 1.1 & 0.1824 & 1.1 & 0.924 \\
\hline $10.1 \mathrm{r}$ & 0.00 & 270 & 149 & 0.57 & 41.2 & 1054 & \pm 11 & 1031 & \pm 15 & -2 & 0.0736 & 0.75 & 1.803 & 1.4 & 0.1777 & 1.1 & 0.832 \\
\hline $11.1 \mathrm{~m}$ & 0.00 & 321 & 122 & 0.39 & 49 & 1056 & \pm 11 & 1075 & \pm 11 & 2 & 0.07526 & 0.57 & 1.846 & 1.2 & 0.1779 & 1.1 & 0.889 \\
\hline $12.1 \mathrm{r}$ & 0.03 & 752 & 50 & 0.07 & 64.1 & 610.1 & \pm 6.2 & 924 & \pm 12 & 34 & 0.06984 & 0.6 & 0.956 & 1.2 & 0.0993 & 1.1 & 0.869 \\
\hline $13.1 \mathrm{~m}$ & 0.00 & 350 & 123 & 0.36 & 56.4 & 1108 & \pm 11 & 1116 & \pm 11 & 1 & 0.07679 & 0.55 & 1.986 & 1.2 & 0.1876 & 1.1 & 0.895 \\
\hline $14.1 \mathrm{~m}$ & 0.00 & 329 & 108 & 0.34 & 51.9 & 1088 & \pm 11 & 1086 & \pm 18 & 0 & 0.07564 & 0.89 & 1.918 & 1.4 & 0.1839 & 1.1 & 0.778 \\
\hline $15.1 \mathrm{~m}$ & 0.02 & 468 & 161 & 0.36 & 71.8 & 1060 & \pm 11 & 1091 & \pm 10 & 3 & 0.07585 & 0.51 & 1.868 & 1.2 & 0.1787 & 1.1 & 0.904 \\
\hline $16.1 \mathrm{r}$ & 0.00 & 183 & 153 & 0.86 & 27.5 & 1042 & \pm 11 & 1044 & \pm 18 & 0 & 0.07411 & 0.87 & 1.793 & 1.5 & 0.1754 & 1.2 & 0.806 \\
\hline
\end{tabular}

Errors are 1-sigma; $\mathrm{Pb}_{\mathrm{c}}$ and $\mathrm{Pb}^{*}$ indicate the common and radiogenic portions, respectively.

Error in Standard calibration was $0.16 \%$ (not included in above errors but required when comparing data from different mounts)

(1) Common Pb corrected using measured ${ }^{204} \mathrm{~Pb}$.

a Zircon characterisation: $\mathrm{m}=$ magmatic, zoned; $\mathrm{c}=$ core; $\mathrm{r}=$ rim or reworked zone.

4.4. Medium-grained mafic granulites (metabasites) from the Munster headland (sample PM07/4)

The morphologies of the grains from this sample were very similar to those of sample PM07/1 (Fig. 8).

A total of 17 grains were analysed (Table 3 ). The magmatic zones provided an age of $1093.1 \pm 5.8 \mathrm{Ma}$, which is probably a crystallization age (Fig. 10). The single metamorphic rim that was analysed gave a $207 / 206$ age of $1021 \pm 22 \mathrm{Ma}$ (Table 3, spot 4.1). A core provided a 207/ 206 age of $1238 \pm 13 \mathrm{Ma}$ (Table 3, spot 14.1).

\subsection{Rim data}

A Concordia plot of the rim data from sample PM07/1 gives an age of $1074 \pm 27 \mathrm{Ma}$ and a concordia plot of all the rim analyses from both samples provides an age of $1065 \pm 23 \mathrm{Ma}$. These (low precision) data suggest a heating event some 20-30 Ma after intrusion.

\section{Discussion}

The intrusive ages of $1091 \pm 7.1 \mathrm{Ma}$ and $1093 \pm 5.8 \mathrm{Ma}$ for these two phases of the Munster Suite are statistically identical indicating that they are coeval. This, in turn, lends some support to the interpretation that these lithologies are consanguineous and derived from a common magma chamber.

Moreover, these ages are also identical to those of the Glenmore Granite which is intruded by Munster Suite metabasites (1091 $\pm 9 \mathrm{Ma}$; Mendonidis et al., 2002), as well as to that of the Portobello Charnockites that intruded the Munster Suite quartz-monzonorites at Palm Beach (1093 $\pm 7.3 \mathrm{Ma}$; Mendonidis and Armstrong, unpublished data).

These data, therefore, suggest that there was an evolving mafic magma chamber (underplating?) beneath the Margate arc, which not only provided the magma for the Munster Suite intrusions, but also the advective heat source for crustal melting that generated the coeval S-type Glenmore and Portobello Granites. Thus there was a 1093 Ma magmatic event during which calc-alkaline mafic rocks (Munster Suite) and S-type granites intruded the Leisure Bay granulites in the Margate Terrane.

The plots of the geochemical data recorded in Mendonidis and Grantham (1989) onto various discrimination diagrams are equivocal.
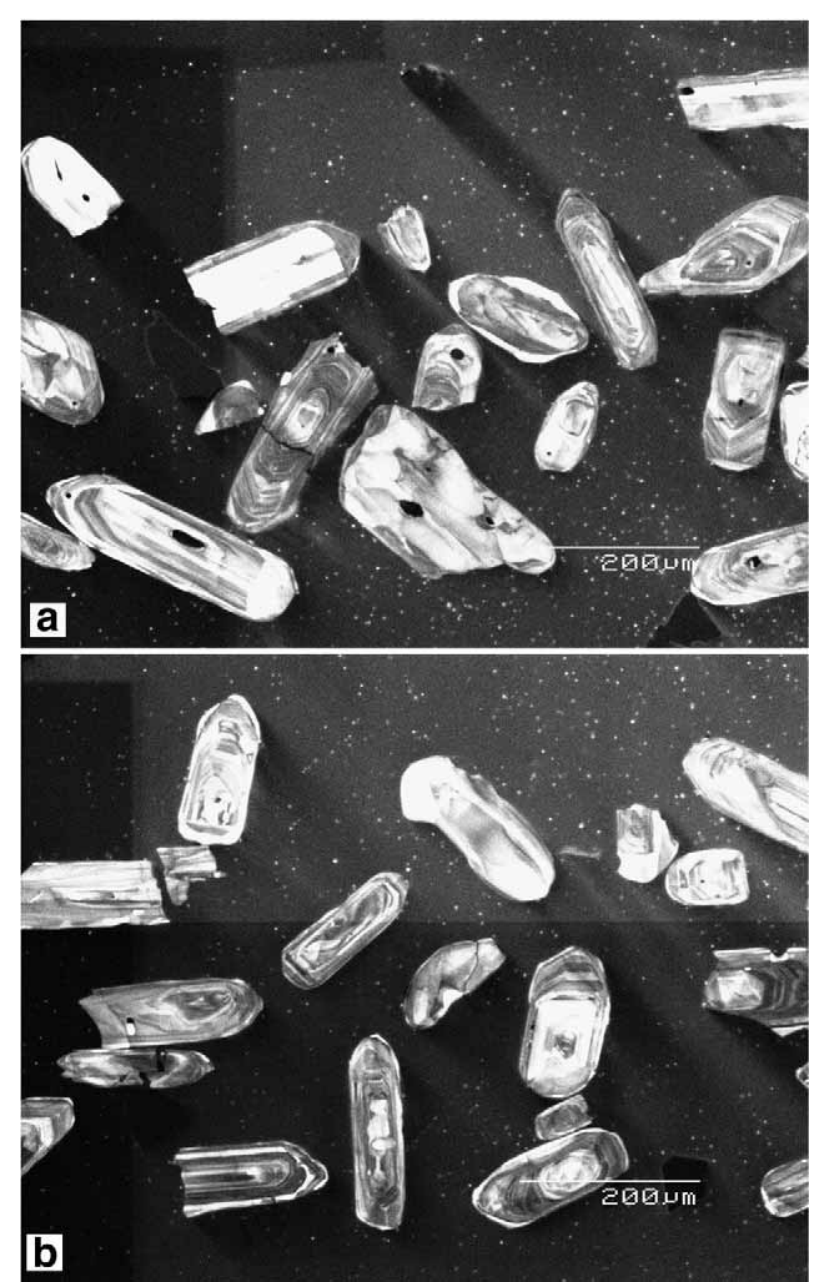

Fig. 8. Cathodoluminescence images of some zircon grains from sample PM07/1 (a) and PM07/4 (b) 
Table 3

Summary of SHRIMP U-Pb zircon data for sample PM07/4

\begin{tabular}{|c|c|c|c|c|c|c|c|c|c|c|c|c|c|c|c|c|c|}
\hline $\begin{array}{l}\text { Grain } \\
\text { spot }^{\mathrm{a}}\end{array}$ & ${ }^{\%}{ }^{206} \mathrm{~Pb}_{\mathrm{c}}$ & $\begin{array}{l}\text { ppm } \\
\text { U }\end{array}$ & $\begin{array}{l}\text { ppm } \\
\text { Th }\end{array}$ & $\begin{array}{l}{ }^{232} \mathrm{Th} / \\
{ }^{238} \mathrm{U}\end{array}$ & $\begin{array}{l}{ }^{206} \mathrm{~Pb}^{*} \\
\text { * }\end{array}$ & ${ }^{(1)^{20}}{ }^{238} \mathrm{U}$ & & $\begin{array}{l}(1)^{207} \mathrm{P} \\
{ }^{206} \mathrm{~Pb} \mathrm{aq}\end{array}$ & & $\begin{array}{l}\% \\
\text { discordant }\end{array}$ & $\begin{array}{l}(1)^{207} \mathrm{~Pb}^{*} / \\
{ }^{206} \mathrm{~Pb}^{*}\end{array}$ & $\pm \%$ & $\begin{array}{l}(1)^{207} \mathrm{~Pb}^{*} / \\
{ }^{235} \mathrm{I}\end{array}$ & $\pm \%$ & ${ }^{(1)^{206}}{ }^{206} \mathrm{~Pb}^{*} /$ & $\pm \%$ & $\begin{array}{l}\text { Err } \\
\text { corr }\end{array}$ \\
\hline $1.1 \mathrm{~m}$ & 0.04 & 619 & 67 & 0.11 & 96 & 1070 & \pm 10 & 1096.9 & \pm 9.5 & 2 & 0.07607 & 0.48 & 1.893 & 1.2 & 0.1805 & 1.1 & 0.912 \\
\hline $2.1 \mathrm{~m}$ & 0.03 & 417 & 147 & 0.36 & 66.9 & 1104 & \pm 11 & 1091 & \pm 11 & -1 & 0.07586 & 0.55 & 1.954 & 1.2 & 0.1868 & 1.1 & 0.891 \\
\hline $3.1 \mathrm{~m}$ & 0.05 & 286 & 86 & 0.31 & 44.6 & 1077 & \pm 11 & 1077 & \pm 15 & 0 & 0.0753 & 0.73 & 1.888 & 1.3 & 0.1818 & 1.1 & 0.841 \\
\hline $4.1 \mathrm{r}$ & 0.14 & 177 & 74 & 0.43 & 25.8 & 1009 & \pm 11 & 1021 & \pm 22 & 1 & 0.07327 & 1.1 & 1.712 & 1.6 & 0.1695 & 1.2 & 0.745 \\
\hline $5.1 \mathrm{~m}$ & 0.00 & 534 & 165 & 0.32 & 83.7 & 1080 & \pm 11 & 1105.7 & \pm 9.4 & 2 & 0.0764 & 0.47 & 1.921 & 1.2 & 0.1824 & 1.1 & 0.916 \\
\hline $6.1 \mathrm{~m}$ & 0.02 & 509 & 178 & 0.36 & 81.5 & 1102 & \pm 11 & 1106 & \pm 12 & 0 & 0.07643 & 0.59 & 1.965 & 1.2 & 0.1865 & 1.1 & 0.876 \\
\hline $7.1 \mathrm{~m}$ & 0.03 & 616 & 192 & 0.32 & 97.9 & 1093 & \pm 11 & 1091.7 & \pm 7.8 & 0 & 0.07587 & 0.39 & 1.934 & 1.1 & 0.1849 & 1.1 & 0.939 \\
\hline $8.1 \mathrm{~m}$ & 0.02 & 291 & 103 & 0.37 & 47.1 & 1113 & \pm 11 & 1082 & \pm 11 & -3 & 0.0755 & 0.55 & 1.962 & 1.2 & 0.1884 & 1.1 & 0.894 \\
\hline $9.1 \mathrm{~m}$ & 0.05 & 744 & 181 & 0.25 & 117 & 1086 & \pm 10 & 1087.6 & \pm 7.7 & 0 & 0.07572 & 0.39 & 1.915 & 1.1 & 0.1834 & 1 & 0.937 \\
\hline $10.1 \mathrm{~m}$ & 0.03 & 351 & 138 & 0.41 & 55.3 & 1087 & \pm 11 & 1095 & \pm 10 & 1 & 0.07601 & 0.52 & 1.924 & 1.2 & 0.1836 & 1.1 & 0.901 \\
\hline $11.1 \mathrm{~m}$ & 0.00 & 603 & 143 & 0.24 & 94.7 & 1083 & \pm 10 & 1100.8 & \pm 7.7 & 2 & 0.07622 & 0.38 & 1.923 & 1.1 & 0.183 & 1 & 0.939 \\
\hline $12.1 \mathrm{~m}$ & 0.02 & 633 & 154 & 0.25 & 100 & 1093 & \pm 10 & 1090 & \pm 7.4 & 0 & 0.07581 & 0.37 & 1.931 & 1.1 & 0.1847 & 1 & 0.942 \\
\hline $13.1 \mathrm{~m}$ & 0.00 & 128 & 101 & 0.81 & 20.5 & 1098 & \pm 12 & 1104 & \pm 16 & 1 & 0.07633 & 0.81 & 1.955 & 1.5 & 0.1857 & 1.2 & 0.833 \\
\hline $14.1 \mathrm{c}$ & - & 160 & 71 & 0.46 & 29.3 & 1247 & \pm 13 & 1238 & \pm 13 & -1 & 0.08169 & 0.67 & 2.403 & 1.3 & 0.2133 & 1.2 & 0.865 \\
\hline $15.1 \mathrm{~m}$ & 0.02 & 535 & 211 & 0.41 & 83.4 & 1074 & \pm 10 & 1096.9 & \pm 8.9 & 2 & 0.07607 & 0.44 & 1.902 & 1.1 & 0.1813 & 1.1 & 0.922 \\
\hline $16.1 \mathrm{~m}$ & 0.00 & 417 & 139 & 0.35 & 67.6 & 1115 & \pm 11 & 1084 & \pm 9.1 & -3 & 0.07558 & 0.46 & 1.967 & 1.2 & 0.1888 & 1.1 & 0.922 \\
\hline $17.1 \mathrm{~m}$ & - & 697 & 238 & 0.35 & 107 & 1062 & \pm 10 & 1097.3 & \pm 7 & 3 & 0.07608 & 0.35 & 1.878 & 1.1 & 0.179 & 1 & 0.948 \\
\hline
\end{tabular}

Errors are 1-sigma; $\mathrm{Pb}_{\mathrm{c}}$ and $\mathrm{Pb}^{*}$ indicate the common and radiogenic portions, respectively.

Error in standard calibration was $0.17 \%$ (not included in above errors but required when comparing data from different mounts).

(1) Common $\mathrm{Pb}$ corrected using measured ${ }^{204} \mathrm{~Pb}$.

a Zircon characterisation: $\mathrm{m}=$ magmatic, zoned; $\mathrm{c}=$ core; $\mathrm{r}=$ rim or reworked zone.

However, the Pearce-type spidergrams indicate a marked Nb depletion relative to MORB and oceanic island basalts (Fig. 5), which is a characteristic of island arc basalts thought to be due to rutile remaining in the restite of partially melted subducted slab (Kelemen et al., 1993). The other incompatible elements also follow the same pattern as that of modern island arcs (Fig. 5), but all show higher concentrations. The high $\mathrm{Zr}$ concentrations explain the data points that plot within withinplate regions of the discrimination diagrams that use $\mathrm{Zr}$ as a discriminant parameter (Fig. 7). Pearce et al. (1995) argued that very little Zr and a small percentage of the $\mathrm{P}$ and Ti concentrations in island arc magmas are contributed by the subducting slab so their origins must be from the mantle wedge overlying the slab and contamination. Therefore, other reasons for the observed enrichment of incompatible elements in the Munster rocks are needed. One possible reason may be that the Munster Suite is more evolved that those of other arcs, supporting the notion of a deeper evolving magma chamber. Other possible explanations include crustal contamination and higher tem- peratures. With regards the former, Eglington et al. $(1986,1989)$ have provided Nd data that suggest that the NMB is largely juvenile crustal material which would eliminate an opportunity for contamination, but the immediately preceding intrusion of the S-type Glenmore Granite suggests that there probably was an opportunity for contamination. Higher concentrations of Zr, Ti and P in the Munster Suite and other lithologies from this region have been discussed by Grantham et al. (2001) who suggest that the cause is high magmatic temperatures. However, although high magmatic temperatures are needed for such high concentrations, they are not the origin.

All things considered, the data suggest that the Munster Suite formed within an island arc context with high heat flow and that it tapped an underlying magma chamber.

The concept of mafic magmatic underplating beneath an arc has been mooted before. For example, Murphy (2006) states that during a prolonged history of subduction, the dip and location of the subduction zone may vary causing the locus of arc magmatism to migrate,

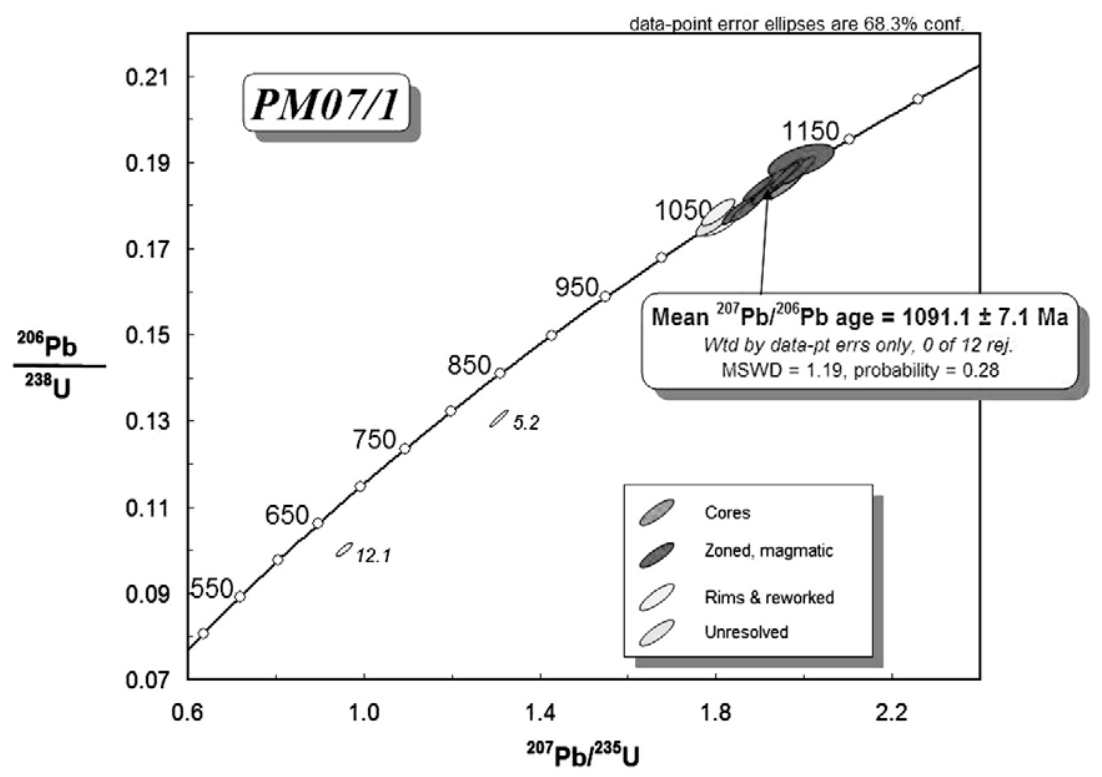

Fig. 9. Wetherill U-Pb Concordia plot of the SHRIMP analyses for the quartz-monzonorites (Munster Suite) cropping out along Palm Beach (sample PM07/1). The Concordia curve is calibrated in millions of years. 


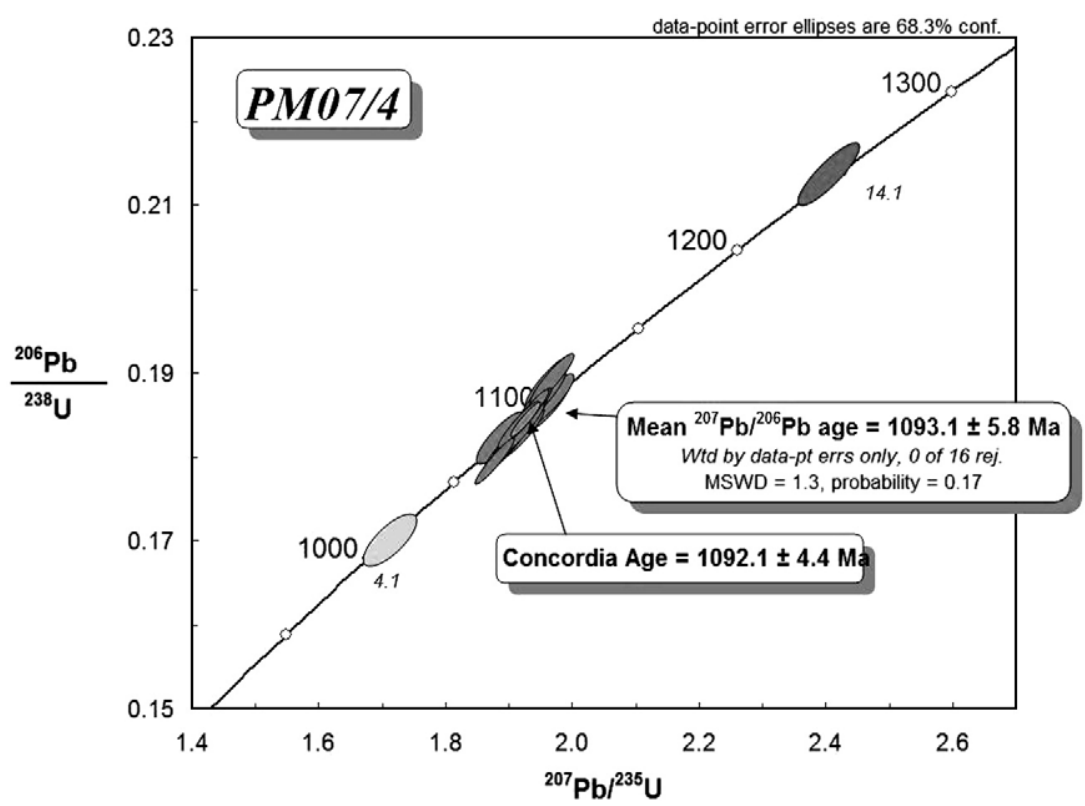

Fig. 10. Wetherill U-Pb Concordia plot of the SHRIMP analyses for the metabasites (Munster Suite) cropping out along the Munster Headland (sample PM07/4). The Concordia curve is calibrated in millions of years.

which in turn causes intermittent switching from compressional to extensional environments, and that during the periods of extension, arcs have a steep geothermal gradient facilitating underplating of the crust by mafic magma which may transfer sufficient heat to induce anatexis.

Magmatic underplating is also supported by the petrologic work of Mendonidis and Grantham (2003) who reported petrographic and thermobarometric evidence for low-pressure, high-temperature metamorphism and anticlockwise pressure-temperature-cooling paths for the M1 event from the Leisure Bay granulites (e.g. Waters 1988, 1989, 1990). This, furthermore, suggests that the M1 metamorphism recorded by the Leisure Bay granulites was related to this $\sim 1093$ Ma magmatic event. The younger ages provided by the rim overgrowths on the zircon grains suggest that M2 occurred some 20$30 \mathrm{Ma}$ later, roughly at the same time as the intrusions of the A-type granitoids of the Oribi Gorge Suite.

Another important consideration is the similarity of these new Munster Suite ages with those of the widespread A-type magmatism in the Natal belt which is characterized by a large number of plutons that range in age from $\sim 1100$ to $\sim 1025 \mathrm{Ma}$ (Eglington et al., 2003; Grantham et al., 2001). Although there is a general southwardyounging spatial-age distribution of these A-type plutons (Grantham et al., 2001), summed probability distribution plots of these ages indicate two distinct pulses of magmatism at $\sim 1070$ and $\sim 1030 \mathrm{Ma}$ (Eglington et al., 2003). The Munster Suite pre-dated both pulses, but appears to have been coeval with the northern-most A-type intrusion.

\section{Conclusions}

U-Pb SHRIMP data indicate crystallization ages of $1091 \pm 7.1 \mathrm{Ma}$ and $1093 \pm 5.8$ Ma for the quartz-monzonorites and metabasites, respectively, of the Munster Suite. The coeval nature of the intrusions supports the earlier interpretation that these lithologies are consanguineous. Moreover, these data also indicate that the Munster Suite is coeval with the S-type granitic rocks in the area (e.g. Glenmore Granite data at $1091 \pm 9 \mathrm{Ma}$ ). Therefore, it is concluded that there was a period of magmatism and crustal growth of the Margate Terrane at about 1093 Ma during which the Leisure Bay metasedimentary rocks were intruded by granitic and mafic magmas. This, together with evidence of low-pressure granulite facies metamorphism and antic- lockwise P-T-t paths in the Leisure Bay granulites (Mendonidis and Grantham, 2003) leads to the proposal that there was mafic underplating beneath the Margate arc that provided both the magma for the Munster Suite and the heat for the generation of the S-type granites. This, in turn, suggests that there was a period of extension during the development of the arc that is now the Margate Terrane. The deformational fabrics within the dated lithologies indicate that deformation and accretion of the Terrane occurred after $\pm 1093 \mathrm{Ma}$. The few analysed metamorphic zircon rims provided data suggesting a thermal event about 20-30 Ma after magma crystallization, roughly coeval with the A-type magmatism in the Margate Terrane.

\section{Acknowledgement}

We gratefully acknowledge the funding for the U-Pb SHRIMP analyses provided by the Vaal University of Technology.

\section{References}

Arima, M., Tani, K., Kawate, S., Johnston, S.T., 2001. Geochemical characteristics and tectonic setting of metamorphosed rocks from the Tugela terrane, Natal belt, South Africa. Memoirs of the National Institute of Polar Research (Japan) 55, 1-39 Special Issue.

Barkhuizen, J.G., Matthews, P.E., 1990. Gravity modeling of the Natal Thrust Front; a Mid-Proterozoic crustal suture in southeastern Africa. Geological Society of South Africa Geocongress '90 Johannesburg. Extended Abstract Volume, pp. 32-35.

Casquet, C., Pankhurst, R.J., Fanning, C.M., Baldo, E., Galindo, C., Rapela, C.W., GonzálezCasado, J.M., Dahlquist, J.A., 2006. U-Pb SHRIMP zircon dating of Grenvillian metamorphism in Western Sierras Pampeanas (Argentina): correlation with the Arequipa-Antofalla craton and constraints on the extent of the Precordillera Terrane. Gondwana Research 9, 524-529.

Compston, W., Williams, I.S., Kirschvink, J.L., Zhang, Z., Ma, G., 1992. Zircon U-Pb ages for the early Cambrian time-scale. Journal of the Geological Society London 149,171-184.

Cumming, G.L., Richards, J.R., 1975. Ore lead isotope ratios in a continuously changing earth. Earth and Planetary Science Letters 28, 155-171.

Dalziel, I.W.D., Mosher, S., Gahagan, L.M., 2000. Laurentia-Kalahari collision and the assembly of Rodinia. Journal of Geology 108, 499-513.

D'el-Rey Silva, LJ.H., Dantas, E.L. Teixeira, J.B.G., Laux, J.H., da Silva, M.G, 2007. U-Pb and Sm-Nd geochronology of amphibolites from the Curaçá Belt, São Francisco Craton, Brazil: tectonic implications. Gondwana Research 12, 454-467.

De Beer, J.H., Meyer, R., 1984. Geophysical characteristics of the Namaqua-Natal belt and its boundaries. Journal of Geodynamics 1, 473-494.

Du Toit, A.L., 1946. The geology of parts of Pondoland, East Griqualand and Natal. Geological Survey of South Africa. Explanation Sheet, vol. 119.

Eglington, B.M., Harmer, R.E., Kerr, A., 1986. Petrographic, Rb-Sr isotope and geochemical characteristics of intrusive granitoids from the Port Edward-Port Shepstone area, Natal. Transactions of the Geological Society of South Africa 89, 199-213. 
Eglington, B.M., Harmer, R.E., Kerr, A., 1989. Isotope and geochemical constraints on Proterozoic crustal evolution in South-Eastern Africa. Precambrian Research 45, 159-174.

Eglington, B.M., Thomas, R.J., Armstrong, R.A., Walraven, F., 2003. Zircon geochronology of the Oribi Gorge Suite, Kwazulu-Natal, South Africa, constraints on the timing of transcurrent shearing in the Namaqua-Natal Belt. Precambrian Research 123, 29-46.

Eglington, B.M., Thomas, R.J., Armstrong, Harmer, R.E., Moen, H.F.G., de Beer, C.H., Grantham, G.H., 2000. Development of the Namaqua-Natal Belt within Rodinia. Journal of African Earth Sciences 31 (1A), 21-22.

Elburg, M.A., Kamenetsky, V.S., Foden, J.D., Sobolev, A., 2007. The origin of medium-K ankaramitic arc magmas from Lombok (Sunda arc, Indonesia): mineral and melt inclusion evidence. Chemical Geology 240, 260-279.

Gevers, T.W., Dunne, J.C., 1942. Charnockitic rocks near Port Edward in Alfred County, Natal. Transactions of the Geological Society of South Africa 45, 183-214.

Grantham, G.H., 1983. The tectonic, metamorphic and intrusive history of the Natal mobile belt between Glenmore and Port Edward, Natal. MSc thesis Natal University, Pietermaritzburg 1-176.

Grantham, G.H., Eglington, B.M., Thomas, R.J., Mendonidis, P., 2001. The nature of the Grenville-age charnockitic A-type magmatism from the Natal, Namaqua and Maud belts of southern Africa and western Dronning Maud Land, Antarctica. Memoirs of National Institute of Polar Research 55, 59-86 Special Issue.

Irvine, T.N., Baragar, W.R.A., 1971. A guide to the chemical classification of the common volcanic rocks. Canadian Journal of earth Science 8, 523-548.

Jacobs, J., Thomas, R.J., Weber, K., 1993. Accretion and indentation tectonics at the southern edge of the Kaapvaal craton during the Kibaran (Grenville) orogeny. Geology 21, 203-206.

Jacobs, J., Bauer, W., Fanning, C.M., 2003. New age constraints for Grenville-age metamorphism in western central Dronning Maud Land (East Antarctica), and implications for the palaeogeography of Kalahari in Rodinia. International Journal of Earth Science 92, 301-315.

Jacobs, J., Hansen, B.T., Henjes-Kunst, F., Thomas, R.J., Weber, K., Armstrong, R.A., Cornell, D.H., 1999. New age constraints on the Proterozoic/Lower Paleozoic evolution of Heimefrontfjella, East Antarctica, and its bearing on Rodinia/Gondwana correlations. Terra Antarctica 6, 377-389.

Johnston, S.T., Armstrong, R.A., Heaman, L., McCourt, S., Mitchell, A.A., Bisnath, A., Arima, A., 2001. Preliminary U-Pb geochronology of the Tugela Terrane, Natal belt, eastern South Africa. Memoirs of the National Institute of Polar Research (Japan) 55, 40-58 Special Issue.

Kelemen, P.B., Shimizu, N., Dunn, T., 1993. Relative depletion of niobium in some arc magmas and the continental crust: Partitioning of K, Nb, La and Ce during melt/rock reaction in the upper mantle. Earth and Planetary Science Letters 120, 111-134.

Machado, A., Lima, E.F., Chemale Jr., F., Morata, D., Oteiza, O., Almeida, D.P.M., Figueiredod, A.M.G., Alexandrea, F.M., Urrutiab, J.L., 2005. Geochemistry constraints of Mesozoic-Cenozoic calc-alkaline magmatism in the South Shetland arc, Antarctica. Journal of South American Earth Sciences 18, 407-425.

Mallmann, G., Chemale Jr., F., Ávila, J.N., Kawashita, K., Armstrong, R.A., 2007. Isotope geochemistry and geochronology of the Nico Pérez Terrane, Rio de la Plata Craton, Uruguay. Gondwana Research 12, 489-508.

Matthews, P.E., 1972. Possible Precambrian obduction and plate tectonics in southeast Africa. Nature 240, 37-39.

McCourt, S., Armstrong, R.A., Grantham, G.H., Thomas, R.J., 2006. Geology and evolution of the Natal Belt, South Africa. Journal of African Earth Sciences 46, 71-92.

Mclver, J.R., 1963. A contribution to the Precambrian geology of southern Natal. PhD thesis University of the Witwatersrand 1-218.

Mclver, J.R., 1966. Orthopyroxene-bearing granitic rocks from southern Natal. Transactions of the Geological Society of South Africa 66, 99-117.

Mendonidis, P., 1989. The tectonic evolution of a portion of the Southern Granulite Zone of the Natal mobile belt, between Southbroom and Glenmore, Natal. PhD thesis. University of Natal, Pietermaritzburg 1-260.

Mendonidis, P., Grantham, G.H., 1989. The distribution, petrology and geochemistry of the mafic to intermediate Munster Suite, south coast, Natal. South African Journal of Geology 92 (4), 377-388.

Mendonidis, P., Strydom, D., 1989. Tectonic history of Proterozoic granulite gneisses between Glenmore and Southbroom, southern Natal. South African Journal of Geology 92 (4), 352-368.

Mendonidis, P., Grantham, G.H., 2003. Petrology, origin and metamorphic history of Proterozoic-aged granulites of the Natal Metamorphic Province, southeastern Africa. Gondwana Research 6, 607-628.

Mendonidis, P., Armstrong, R.A., Eglington, B.M., Grantham, G.H., Thomas, R.J., 2002. Metamorphic history and U-Pb Zircon (shrimp) geochronology of the Glenmore Granite: implications for the tectonic evolution of the Natal Metamorphic Province. South African Journal of Geology 105, 325-336.

Meschede, M., 1986. A method of discriminating between different types of mid-ocean ridge basalts and continental tholeiites with the $\mathrm{Nb}-\mathrm{Zr}-\mathrm{Y}$ diagram. Chemical Geology 56, 207-218.

Mozier, M., Robin, C. Eissen, J.-P., Cotton, J., 1997. Geochemistry vs, seismo-tectonics along the volcanic New Hebrides Central Chain (Southwest Pacific). Journal of Volcanology and Geothermal Research 78, 1-29.

Mullen, E.D., 1983. MnO/TiO2/P2O5: a minor element discriminant for basaltic rocks of oceanic environments and its implications for petrogenesis. Earth and Planetary Science Letters 62, 53-62.
Murphy, J.B., 2006. Igneous rock associations 7. Arc magmatism I: relationship between subduction and magma genesis. Geoscience Canada 33 (4), 145-167.

Nicholaysen, L.O., Burger, A.J., 1965. Note on the extensive zone of 1000 million year old metamorphic-igneous rocks in southern Africa. Scientia De La Terra, 10 (Int. Coll. Nancy 1965), pp. 497-516.

Paces, J.B., Miller, J.D., 1989. Precise U-Pb ages of Duluth Complex and related mafic intrusions, Northeastern Minnesota: geochronological insights to physical, petrogenic, palaeomagnetic and tectonomagmatic processes associated with the $1.1 \mathrm{Ga}$ miscontinent rift system. Journal of Geophysical Research 98B, 13997-14013.

Paulsen, S., Encarnación, J., Grunow, A.M., Layer, P.W., Watkeys, M., 2007. New age constraints for a short pulse in Ross orogen deformation triggered by East-West Gondwana suturing. Gondwana research $12,417-427$.

Pearce, J.A., 1983. Role of the sub-continental lithosphere in magma genesis at active continental margins. In: Hawksworth, C.J., Norry, M.J. (Eds.), Continental Basalts and Mantle Xenoliths Shiva, Nantwich, pp. 230-249.

Pearce, J.A., Cann, J.R., 1973. Tectonic setting of basic volcanic rocks determined using trace element analyses. Earth and Planetary Science letters 19, 290-300.

Pearce, J.A., Norry, M.J., 1979. Petrogenetic implications of Ti, Zr, Y, and Nb variations in volcanic rocks. Contributions to Mineralogy and Petrology 69, 33-47.

Pearce, J.A., Baker, P.E., Harvey, P.K., Luff, I.W., 1995. Geochemical evidence for subduction fluxes, mantle melting and fractional crystallization beneath the South Sandwich Island Arc. Journal of Petrology 36 (4), 1073-1109.

Santosh, M., Morimoto, T., Tsutsumi, Y., 2006a. Geochronology of the khondalite belt of Trivandrum Block, Southern India: electron probe ages and implications for Gondwana tectonics. Gondwana Research 9, 261-278.

Santosh, M., Collins, A.S., Tamashiro, I., Koshimoto, S., Tsutsumi, Y., Yokoyama, K., 2006b. The timing of ultrahigh-temperature metamorphism in Southern India: U-Th-Pb electron microprobe ages from zircon and monazite in sapphirine-bearing granulites. Gondwana Research 10, 128-155.

Skridlaite, G., Baginski, B. and Whitehouse, M., in press. Significance of $\sim 1.5$ Ga zircon and monazite ages from charnockites in southern Lithuania and NE Poland. Gondwana Research.

Sun, S.S., 1980. Lead isotopic study of young volcanic rocks from mid ocean ridges, oceanic islands and island arcs. Philosophical Transactions of the Royal Society of London A297, 409-445.

Talbot, C.J., Grantham, G.H., 1987. The Proterozoic intrusion and deformation of deep crustal "sills" along the south coast of Natal. South African Journal of Geology 90 (4), $520-538$.

Thomas, R.J., 1988a. The Geology of the Port Shepstone Area. Explanation, sheet 3030 (1:250000). Geological Survey of South Africa. 136pp.

Thomas, R.J., 1988b. The petrology of the Oribi Gorge Suite: Kibaran charnockitic granitoids from southern Natal. South African Journal of Geology 91, 425-454.

Thomas, R.J., 1989. A tale of two tectonic terranes. South African Journal of Geology 92 (4) 306-321.

Thomas, R.J., Eglington, B.M., 1990. A Rb-Sr, Sm-Nd and U-Pb zircon isotopic study of the Mzumbe Suite, the oldest intrusive granitoids in southern Natal, South Africa. South African Journal of Geology 93, 761-765.

Thomas, R.J., Eglington, B.M., Bowring S.A. Retief, E.A., Walraven, F., 1993a. New isotope data from a Late Proterozoic porphyritic granite-charnockite association from Natal, South Africa. Precambrian Research 62, 83-101.

Thomas, R.J., Eglington, B.M., Bowring, S.A., 1993b. Dating the cessation of Kibaran magmatism in Natal, South Africa. Journal of African Earth Science 16, 247-252.

Thomas, R.J., Cornell, D.H., Armstrong, R.A., 1999. Provenance age and metamorphic history $f$ the Quha Formation, Natal Metamorphic Province: a U-Th-Pb zircon SHRIMP study. South African Journal of Geology 102, 83-88.

Thomas, R.J., Armstrong, R.A., Eglington, B.M., 2003. Geochronology of the Sikombe Granite, Transkei, Natal Metamorphic Province, South Africa. South African Journal of Geology 106, 403-408.

Vermeesch, P., 2006. Tectonic discrimination diagrams revisited. Geochemistry, Geophysics, Geosystems 7, Q06017. doi:10.1029/2005GC001092.

Wang, Y., Fan, W., Zhao, G., Ji, S., Peng, T., 2007. Zircon U-Pb geochronology of gneissic rocks in the Yunkai massif and its implications on the Caledonian event in the South China Block. Gondwana Research 12, 404-416.

Waters, D.J., 1990. Thermal history and tectonic setting of the Namaqualand granulites, southern Africa: clues to Proterozoic crustal development. In: Vielzeuf, D., Vidal, Ph. (Eds.), Granulites and Crustal Evolution. Kluwer, pp. 243-256.

Waters, D.J., 1989. Metamorphic evidence for the heating and cooling path of Namaqualand granulites. In: Daly, J.S., Cliff, R.A., Yardley, B.W.D. (Eds.), Evolution of Metamorphic Belts. . Geological Society of London special publication, vol. 43. Blackwell, London, pp. 357-363.

Waters, D.J., 1988. Partial melting and the formation of granulite facies assemblages in Namaqualand, South Africa. Journal of Metamorphic Geology 6, 387-404.

Williams, I.S., Claesson, S., 1987. Isotopic evidence for the Precambrian provenance and Caledonian metamorphism of high grade paragneisses from the Seve Nappes, Scandinavian Caledonides. II. Ion microprobe zircon U-Th-Pb. Contributions to Mineralogy and Petrology 97, 205-217. 